\title{
Methamphetamine-Induced Sensitization of Dopamine Release via a Metabotropic Glutamate Receptor Mediated Pathway in Rat Striatal Slices
}

\author{
Ikumi Arai $^{1}$, Takao Shimazoe ${ }^{1, *}$, Shigenobu Shibata ${ }^{2}$, Hirotaka Inoue ${ }^{1}$, Akiko Yoshimatsu $^{1}$ and Shigenori Watanabe \\ ${ }^{\prime}$ Department of Pharmacology, Faculty of Pharmaceutical Sciences, Kyushu University 62, Fukuoka 812-82, Japan \\ ${ }^{2}$ Department of Pharmacology, School of Human Sciences, Waseda University, Tokorozawa, Saitama 359, Japan
}

Received October 4, 1996 December 27, 1996

\begin{abstract}
We studied the roles of metabotropic glutamate receptors in methamphetamine (MAP)induced sensitization of dopamine (DA) release from striatal slices. Rats were first treated with MAP $(1 \mathrm{mg} / \mathrm{kg}$, i.p.) once daily for 6 consecutive days. After a 6-day withdrawal, DA release from striatal slices evoked by \pm -1-aminocyclopentane-trans-1,3-dicarboxylic acid (trans-ACPD) was measured. transACPD-induced DA release was significantly enhanced in MAP-sensitized rats, but the inactive form of trans-ACPD (1R,3S-ACPD) did not enhance DA release. The active form of trans-ACPD (1S,3R-ACPD) $(0.1 \mathrm{mM})$-evoked DA release was attenuated by treatment with $0.4 \mathrm{mM}$ RS- $\alpha$-methyl-4-carboxyphenylglycine, a metabotropic glutamate receptor antagonist. The present results suggest that metabotropic glutamate receptors play an important role in expression of MAP-induced sensitization.
\end{abstract}

Keywords: Methamphetamine-induced sensitization, Striatal dopamine release, Metabotropic glutamate receptor

Glutamate receptors (GluRs) mediate excitatory neurotransmission in the brain and are important in neural plasticity such as long-term potentiation (LTP) and longterm depression (LTD). There are both ionotropic and metabotropic GluRs.

Ionotropic GluRs are known to mediate most of the conventional fast excitatory transmission in the central nervous system. Recently, we demonstrated that longterm enhancement (LTE) of striatal dopamine (DA) release occurred after activation of $N$-methyl-D-aspartate receptors (NMDARs) and DL- $\alpha$-amino-3-hydroxy-5methyl-isoxazole propionic acid receptors (AMPARs) (1). On the other hand, metabotropic glutamate receptors (mGluRs) are known to be coupled to alterations in cAMP formation and phosphatidylinositol turnover and activation of phospholipase $D$. mGluRs have also been implicated in LTD in the cerebellum (2) and striatum (3). LTD in the striatum requires the activation of both mGluR and DA receptors (3). In the striatum, mGluRs are present in widely varying relative densities and cellular patterns (4). Corticostriatal Glu and nigrostriatal DA neurons are thought to interact closely and to play im-

\footnotetext{
* To whom correspondence should be addressed.
}

portant roles in neural plasticity in the striatum. In our previous report, the data we obtained by the microdialysis technique suggested that mGluRs are involved in the expression of methamphetamine (MAP)-induced sensitization (5).

The purpose of the present study was to investigate the role of mGluRs in DA release from striatal slices of MAP sensitized rats.

The animals used in the present experiment were male rats of the Wistar strain (Seiwa Animal Co., Fukuoka), weighing between $300-400 \mathrm{~g}$. The rats were housed under a constant temperature $\left(23 \pm 2^{\circ} \mathrm{C}\right)$ and a 12-hr light/dark cycle (light period: $07.00-19.00 \mathrm{hr}$ ). The rats were allowed free access to food and water throughout the experiment.

MAP (Dainippon Pharmaceuticals, Ltd., Osaka) (1.0 $\mathrm{mg} / \mathrm{kg}$, i.p.) or saline (SAL) was administered once daily for 6 consecutive days. On the 6 th day following the last injection of MAP, the rats were anesthetized with ether and decapitated. The brains were rapidly removed in icecold Krebs-Ringer solution $(118.0 \mathrm{mM} \mathrm{NaCl}, 4.7 \mathrm{mM}$ $\mathrm{KCl}, 1.3 \mathrm{mM} \mathrm{CaCl}_{2}, 1.2 \mathrm{mM} \mathrm{MgCl}, 1.0 \mathrm{mM} \mathrm{NaH}_{2} \mathrm{PO}_{4}$, $25.0 \mathrm{mM} \mathrm{NaHCO}$ and $11.0 \mathrm{mM}$ D-glucose) at $\mathrm{pH} 7.4$, equilibrated with a $95 \% \mathrm{O}_{2} / 5 \% \mathrm{CO}_{2}$ gas mixture and cut 
sagittally into $450-\mu \mathrm{M}$-thick slices by a tissue slicer (TC-2; Sorvall, Newtown, CT, USA). The striatal part including the white matter between the neocortex and neostriatum of the slices was dissected out in ice-cold Krebs-Ringer solution. After a 1-hr preincubation period, the striatal slices were placed on a dish in $1 \mathrm{ml}$ of trans-ACPD-, 1S,3R-ACPD-, 1R,3S-ACPD- and/or RS- $\alpha$-methyl-4-carboxyphenylglycine (MCPG)- (Tocris Cookson, Ltd., Bristol, UK) containing solution and incubated for 10 min at $37^{\circ} \mathrm{C}$. NMDA was dissolved in $\mathrm{Mg}^{2+}$ free Ringer solution. MCPG was pre-treated $10 \mathrm{~min}$ before the $1 \mathrm{~S}, 3 \mathrm{R}$ ACPD application. At the end of the incubation time, the solution was transferred immediately to a sample cup containing $100 \mu$ of $0.5 \mathrm{M} \mathrm{HClO}_{4}$ for quantification of DA release into the medium. The striatal tissue containing DA was extracted with $200 \mu \mathrm{l}$ of $0.5 \mathrm{M} \mathrm{HClO}_{4}$ containing $0.1 \% \mathrm{Na}_{2} \mathrm{~S}_{2} \mathrm{O}_{5}$ and $0.1 \%$ EDTA by sonication in sample cups on ice. After centrifugation at $10,000 \mathrm{rpm}$ for $10 \mathrm{~min}$ at $4^{\circ} \mathrm{C}$, supernatants of both the incubation and sonicated solutions were collected for measurement of DA content. DA content was determined with an HPLC-ECD system including a reverse-phase HPLC column (ODS1181, $3 \mu \mathrm{M}, 6.0 \mathrm{~mm} \times 250 \mathrm{~mm}$; Erma, Tokyo) and ECD (E-100; Eicom, Kyoto). The electrode potential was set at $+0.65 \mathrm{~V}$ against the $\mathrm{Ag} / \mathrm{AgCl}$ reference electrode. The mobile phase consisted of $0.5 \mathrm{~g} / \mathrm{l}$ sodium 1 -heptanesulfonate (Tokyo Kasei Inc., Tokyo), $1 \mathrm{mM}$ EDTA (Sigma, St. Louis, MO, USA), 8\% acetonitrile (Hayashi Pure Chemical, Osaka), and was adjusted to pH 3.0 with ortho-phosphoric acid (Merck, Darmstadt, FRG). The flow rate was $1.0 \mathrm{ml} / \mathrm{min}$ (model 510 ; Waters, Milford, MA, USA). Percentage of release was calculated using the values obtained for the DA content in the incubation medium (A) and the DA content remaining in the tissue (B) using the following equation:

$\%$ of total DA $=100 \times A /(A+B)$.

Data were expressed as the means \pm S.E.M. Significant differences between groups were determined by a one-way ANOVA followed by Student's $t$-test for individual comparisons.

Basal DA release from striatal slices in MAP sensitized rats was $2.93 \pm 0.42 \%$ of the total DA content, and this value was not different from SAL-treated rats $(2.73 \pm 0.46 \%$ of the total DA content). In addition, the total contents of DA in the striatum were not different between the two groups (data not shown).

Figure 1A shows trans-ACPD-evoked DA release from striatal slices in SAL-treated or MAP-sensitized rats. trans-ACPD did not cause DA release at any concentration in SAL-treated rats, whereas the DA release in MAP-sensitized rats was significantly and dose-dependently enhanced by trans-ACPD $(\mathrm{P}<0.05, \mathrm{P}<0.01)$. $1 R, 3 S-A C P D$, the inactive form of trans-ACPD, failed to enhance DA release from striatal slices in MAP-sensitized rats (Fig. 1A). DA release induced by $10^{-4} \mathrm{M} 1 \mathrm{~S}, 3 \mathrm{R}^{-}$ ACPD, the active form of trans-ACPD, was $5.70 \pm 0.74 \%$ in SAL-treated rats. On the other hand, it was $8.82 \pm 0.61 \%$ of the total DA content in MAP sensitized rats $(P<0.001)$. The enhancement of $D A$ release by 1S,3R-ACPD was significantly attenuated by MCPG $(6.27 \pm 0.41 \%$ of the total DA content, $\mathrm{P}<0.001)$ (Fig. 1B).

The present results indicate that the mGluR agonist trans-ACPD can enhance DA release from striatal slices of MAP-sensitized rats. trans-ACPD is a selective agonist for the mGluR (6), but it is a relatively poor agonist for phosphoinositide-linked mGluRs. trans-ACPD is a racemic mixture of $1 \mathrm{~S}, 3 \mathrm{R}$ - and $1 \mathrm{R}, 3 \mathrm{~S}$-isomers. Of these isomers, 1S,3R-ACPD is responsible for the mGluR agonist activity because in contrast to $1 \mathrm{R}, 3 \mathrm{~S}-\mathrm{ACPD}$, it is a highly selective and efficacious stimulator of brain phosphoinositide hydrolysis. Furthermore, the depressant effects of 1S,3R-ACPD on forskolin-stimulated cyclic AMP synthesis in rat cerebral cortical slices are antagonized by MCPG (7). In addition, MCPG also antagonizes the effect on phosphoinositide-linked mGluRs in rat cerebral cortex (8). Therefore, this study suggests that the activation of phosphoinositide-linked mGluRs on dopaminergic terminals induce the enhancement of DA release from striatal slices in MAP-sensitized rats. Recently, we reported that mGluRs play important roles in MAP-sensitization from the data obtained by the microdialysis technique (5). The previous data is consistent with the present in vitro results.

Since the initial reports demonstrating that L-Glu stimulates the release of $\left[{ }^{3} \mathrm{H}\right] \mathrm{DA}$ from rat striatal slices (9), numerous studies have been devoted to this presynaptic regulation. In addition, the important role of retrograde messengers like nitric oxide (NO) in synaptic transmission and synaptic plasticity is reported. Actually, we recently demonstrated that NO synthase inhibitors attenuated MAP-induced sensitization (10). mGluR expressed in striatal neuron cell body is thought to mediate striatal LTD through a postsynaptic receptor mechanisms (3). mGluR are also reported to regulate DA release directly or indirectly in the nucleus accumbens (11). Moreover, using the microdialysis technique, we reported that DA release is induced by the activation of mGluR in the nucleus accumbens (12). Thus, it is likely that activation of mGluR may enhance striatal DA release in MAPsensitized rats. Therefore, the present results support an interaction between the metabotropic glutaminergic and dopaminergic systems in the striatum. The activation of striatal mGluRs by $1 \mathrm{~S}, 3 \mathrm{R}-\mathrm{ACPD}$ produces rotational behavior that is mediated via a functional interaction with striatal DA neurons and their receptors (13). In addition, 
A

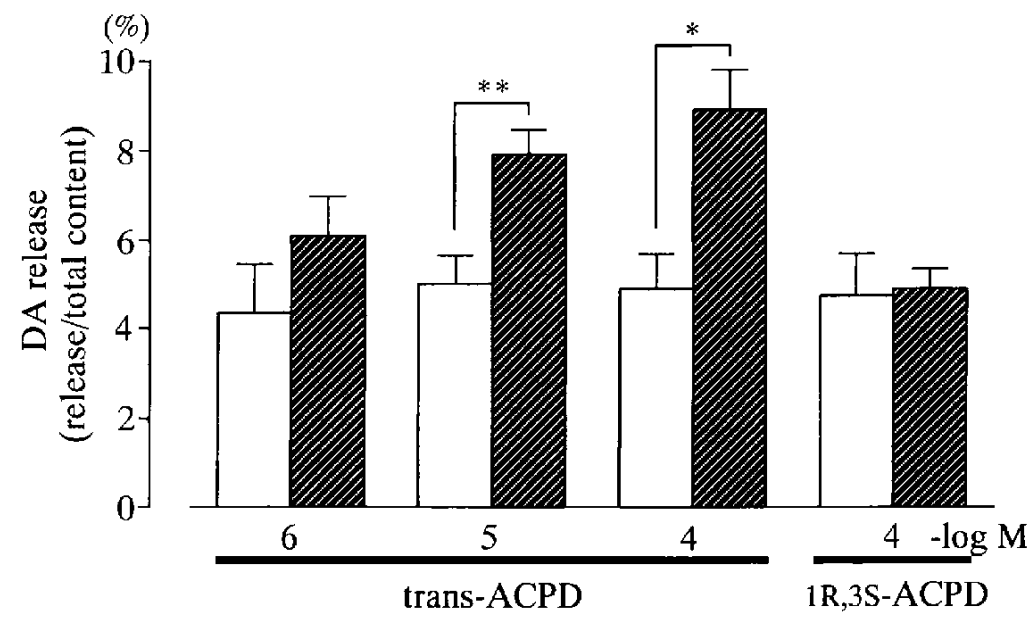

B

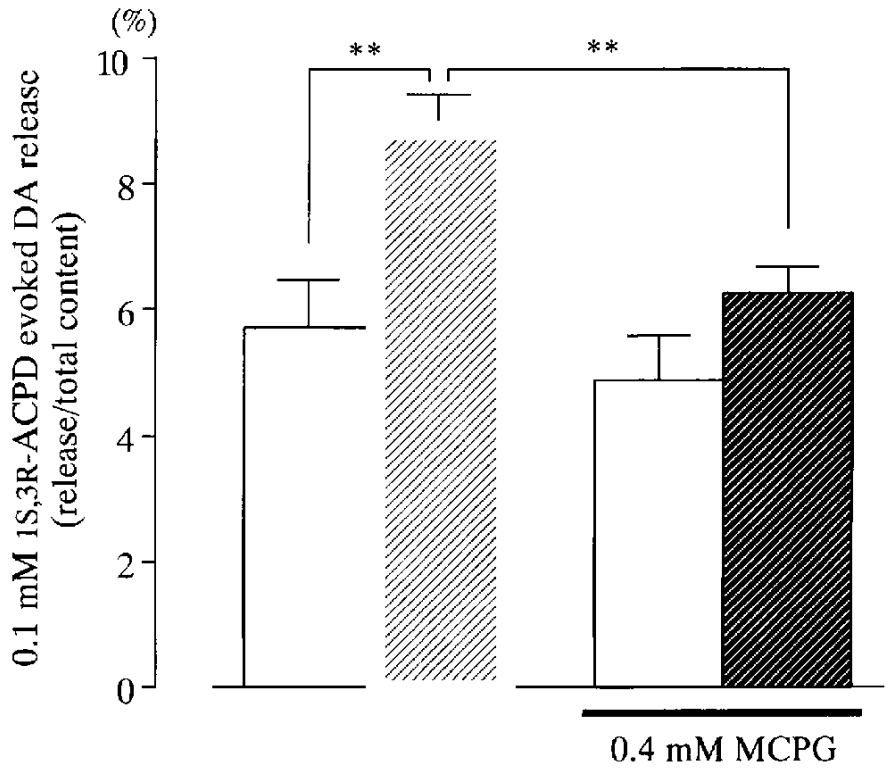

$\operatorname{SAL}(\mathrm{n}=5) \quad \operatorname{MAP}(\mathrm{n}=6)$

Fig. 1. Effects of metabotropic glutamate receptor agonist and antagonist on dopamine (DA) release in methamphetamine (MAP)-sensitized rats. Panel A shows the effect of active and inactive form of trans-ACPD on DA release from striatal slices in MAP-sensitized rats. The rat received saline (SAL) or $1.0 \mathrm{mg} / \mathrm{kg}$ MAP once daily for 6 consecutive days, and after a 6-day withdrawal, striatal slices were prepared. trans-ACPD-induced DA release for 10 min was measured by HPLC. The data are shown as means \pm S.E.M. The data were analyzed by one-way ANOVA followed by Student's $t$-test for individual comparisons. $\left({ }^{* *} \mathbf{P}<0.01,{ }^{*} \mathbf{P}<0.05\right)$. Panel $\mathbf{B}$ shows the effect of a metabotropic glutamate receptor antagonist on enhancement of the active form of trans-ACPD-induced DA release in MAP-sensitized rats. The rat received SAL or $1.0 \mathrm{mg} / \mathrm{kg}$ MAP once daily for 6 consecutive days, and after a 6-day withdrawal, striatal slices were prepared. trans-ACPD-evoked DA release for 10 min was measured. RS- $\alpha$-Methyl-4-carboxyphenylglycine (MCPG) was pre-treated 10 min before the 1S,3R-ACPD application. The data are shown as means \pm S.E.M. $\left({ }^{* *} \mathrm{P}<0.01\right.$ by Student's $t$-test). 
it has been reported that $1 \mathrm{~S}, 3 \mathrm{R}-\mathrm{ACPD}$ causes behavioral changes such as face washing and scratching (14). In the striatum, the activation of mGluRs may influence MAPinduced behavioral sensitization on locomotor activity and the stereotyped behaviors through enhancement of DA release or directly.

In summary, the present study demonstrates that mGluRs may be involved the expression of MAP-induced sensitization.

\section{REFERENCES}

1 Ochi $\mathrm{M}$, Inoue $\mathrm{H}$, Koizumi S, Shibata $\mathrm{S}$ and Watanabe S: Long-term enhancement of dopamine release by high frequency tetanic stimulation via a $N$-methyl-D-aspartate-receptor-mediated pathway in rat striatum. Neuroscience 66, 29-36 (1995)

2 Linden DJ, Dickinson MH, Smeyne $M$ and Connor JA: A long-term depression of AMPA currents in cultured cerebellar Purkinje neurons. Neuron 7, 81-89 (1991)

3 Calabresi P, Roberto M, Mercuri NB and Bernardi G: Coactivation of $\mathrm{D} 1$ and $\mathrm{D} 2$ dopamine receptors is required for longterm synaptic depression in the striatum. Neurosci Lett 142, 95-99 (1992)

4 Testa CM, Standaert DG, Young AB and Penney JB Jr: Metabotropic glutamate receptor mRNA expression in the basal ganglia of the rat. J Neurosci 14, 3005-3018 (1994)

5 Arai I, Shimazoe T, Shibata S, Inoue H, Yoshimatsu A and Watanabe S: Enhancement of dopamine release from the striatum through metabotropic glutamate receptor activation in methamphetamine sensitized rats. Brain Res 729, 277-280 (1996)

6 Palmer E, Monaghan DT and Cotman CW: Trans-ACPD, a selective agonist of the phosphoinositide-coupled excitatory amino acid receptor. Eur J Pharmacol 166, 585-587 (1989)

7 Kemp M, Roberts P, Pook P, Jane D, Jones A, Jones P, Sunter $D$, Udvarhelyi $P$ and Watkins $J$ : Antagonism of presynaptically mediated depressant responses and cyclic AMP-coupled metabotropic glutamate receptors. Eur J Pharmacol Mol Pharmacol 266, 187- 192 (1994)

8 Eaton SA, Jane DE, St Jones PL, Porter RHP, Pook PC-K, Sunter DC, Udvarhelyi PM, Roberts PJ, Salt TE and Watkins $\mathrm{JC}$ : Competitive antagonism at metabotropic glutamate receptors by (S)-4-carboxyphenylglycine and (RS)- $\alpha$-methyl-4-carboxyphenylglycine. Eur J Pharmacol 244, 195-197 (1993)

9 Giorguieff MF, Kemel ML and Glowinski J: Presynaptic effect of L-glutamic acid on the release of dopamine in rat striatal slices. Neurosci Lett 6, 73-77 (1977)

10 Inoue $\mathrm{H}$, Arai I, Shibata $S$ and Watanabe S: L-NAME attenuates the maintenance and expression of methamphetamineinduced behavioral sensitization and enhancement of striatal DA release. J Pharmacol Exp Ther 277, 1424-1430 (1995)

11 Taber MT and Fibiger HC: Electrical stimulation of the prefrontal cortex increases dopamine release in the nucleus accumbens of the rat: modulation by metabotropic glutamate receptors. J Neurochem 15, 3896-3904 (1995)

12 Ohno $M$ and Watanabe S: Persistent increase in dopamine release following activation of metabotropic glutamate receptors in the rat nucleus accumbens. Neurosci Lett 200, 113-116 (1995)

13 Sacaan AI, Bymaster FP and Schoepp DD: Metabotropic glutamate receptor activation produces extrapyramidal motor system activation that is mediated by striatal dopamine. J Neurochem 59, 245-251 (1992)

14 Laudrup P and Klitgaard H: Metabotropic and ionotropic excitatory amino acid receptor agonists induce different behavioral effects in mice. Eur J Pharmacol 250, 15-22 (1993) 